\title{
Vodcasting: digital resource for academic tutoring in the methodology of face-to- face teaching of students in the subjects of technological training, networks and programming
}

\section{Vodcasting: recurso digital para la tutoría académica en la modalidad de enseñanza presencial de los estudiantes en las asignaturas de formación tecnológica, redes y programación}

HIDALGO-BAEZA, María del Carmen†*, HERNÁNDEZ-RAMÍREZ, María Guadalupe, MARTÍNEZROMÁN, Alejandro and CASAS-GÓMEZ, Víctor Manuel

\author{
Universidad Tecnológica Fidel Velázquez, Calle Emiliano Zapata S/N Col. El Tráfico Nicolás Romero Estado de México. \\ ID $1^{\text {st }}$ Author: María del Carmen, Hidalgo-Baeza / ORC ID: 0000-0002-9768-3965, Researcher ID Thomson: S-7675- \\ 2018 \\ ID $1^{\text {st }}$ Coauthor: María Guadalupe, Hernández-Ramírez / ORC ID: 0000-0002-7001-8105, Researcher ID Thomson: S- \\ 6810-2018 \\ ID $2^{\text {nd }}$ Coauthor: Alejandro, Martínez-Román / ORC ID: 0000-0001-8009-6353, Researcher ID Thomson: S-7699-2018 \\ ID $3^{\text {rd }}$ Coauthor: Víctor Manuel, Casas-Gómez / ORC ID: 0000-0002-0195-8910, Researcher ID Thomson: S-7776-2018
}

DOI: $10.35429 /$ JSETM.2019.4.3.29.37

Received February 18, 2019; Accepted June 29, 2019

\begin{abstract}
The objective of this work is to present the research that was carried out with the students and faculty of the Academic Divisions of Networks and Telecommunications and Computer Systems, where the didactic resources and learning strategies were identified, which are used for academic advising with students in the subject of programming and networks. The investigation that was applied was of quantitative type, a questionnaire in Google drive with closed response questions was used as an information gathering instrument and the sample that was taken was about the students enrolled in the second and third semester. Where it was identified that $90.6 \%$ of students and $100 \%$ of teachers would like the incorporation of videos as a strategy for understanding a specific topic. Derived from the result obtained, Vodcast was designed as a didactic resource that strengthens the learning and professional skills of the University Higher Technician (TSU).
\end{abstract}

\begin{abstract}
Resumen
El objetivo de este trabajo es presentar la investigación que se realizó con los estudiantes y profesorado de las Divisiones Académicas de Redes y Telecomunicaciones y Sistemas Informáticos, donde se identificaron los recursos didácticos y estrategias de aprendizaje, que se utilizan para las asesorías académicas con estudiantes en la asignatura de programación y redes. La investigación que se aplico fue de tipo cuantitativa, se utilizó como instrumento de recopilación de información un cuestionario en Google drive con preguntas de respuesta cerrada y la muestra que se tomó fue sobre los estudiantes inscritos en el segundo y tercer cuatrimestre. Donde se identificó que un 90,6\% de alumnos y $100 \%$ de los profesores les gustaría la incorporación de videos como estrategia para comprensión de un tema específico. Derivado del resultado obtenido se diseñó un Vodcast como un recurso didáctico que fortalece el aprendizaje y las competencias profesionales del Técnico Superior Universitario (TSU).
\end{abstract}

Vodcast, Recurso digital, Tutoría académica

Vodcast, Digital resource, Academic tutoring

Citation: HIDALGO-BAEZA, María del Carmen, HERNÁNDEZ-RAMÍREZ, María Guadalupe, MARTÍNEZ-ROMÁN, Alejandro and CASAS-GÓMEZ, Víctor Manuel. Vodcasting: digital resource for academic tutoring in the methodology of face-to-face teaching of students in the subjects of technological training, networks and programming. Journal Schools of economic Thought and Methology. 2019. 3-4: 29-37.

\footnotetext{
* Correspondence to Author (email: mchidalgo70@yahoo.com.mx)

$\dagger$ Researcher contributing as first author.
} 


\section{Introduction}

In this work we have considered the development of a digital resource (Vodcasting) applied in academic tutoring that strengthens the teaching-learning process of underperforming students to improve their use during the current semester or those who have failed a subject and require special advice.

On the other hand, there are subjects that require a different approach to the rest, for this type of subject the teacher being the main actor in the teaching-learning process, needs to generate new strategies such as the use of playful digital materials that facilitate the understanding of a topic of the subject he teaches.

For this purpose, vodcast is proposed, as a digital resource for academic tutoring, in the face-to-face teaching modality, of the technology training subjects of the University Higher Technician (TSU) degree program in Information Technology Infrastructure area of Digital Networks and Computer Systems.

Vodcast is an audio and video file stored in digital form that can be downloaded from the Internet and played on a computer or MP3 player (Dictionary, 2019). The developed vodcasts can be downloaded later on a web page or educational platform, by the students to be reproduced at any time, either a personal computer or a mobile device as support material for the classes as a reference to some content of the subjects of Object Oriented Programming and Data Networks.

\section{Problem}

The subject-oriented Programming subject has as its prerequisite the subject of Programming Methodology that are taught in the first and second four-month period of the Digital Network and Computer Systems Infrastructure careers. The objective of the subject is to develop technological solutions through fundamentals of object-oriented programming. At the Fidel Velázquez Technological University, it establishes groups of 30 students and with a fulltime professor who must distribute their 40 hours per week as follows: 15 in class versus group, 15 to develop teaching materials and research on them and 10 in provide advice and tutoring to the students of the group.
In the study carried out in graphic 1 , it is observed that in the period 2017-1 and 2017-2 the students have a greater problem in the programming subject where the student must have the professional skills to develop software applications through programming oriented to objects.

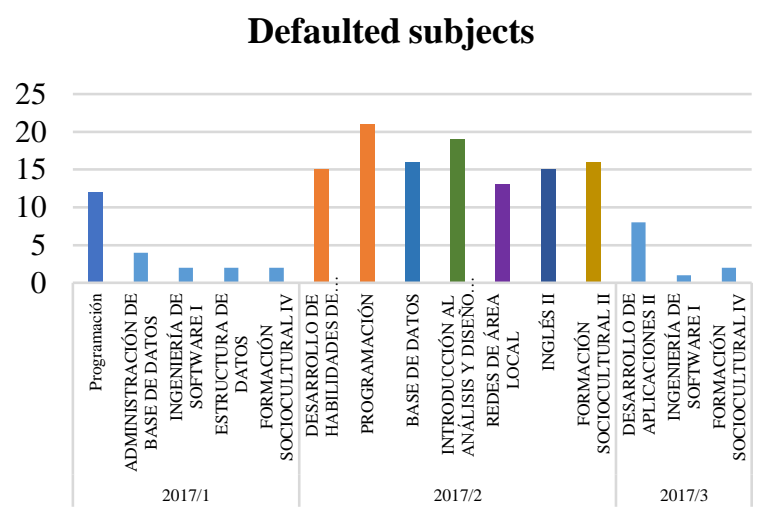

Graphic 1 Materials failed in 2017

Graphic 2 in the 2018-1 period shows that the largest number of students failed the programming subject.

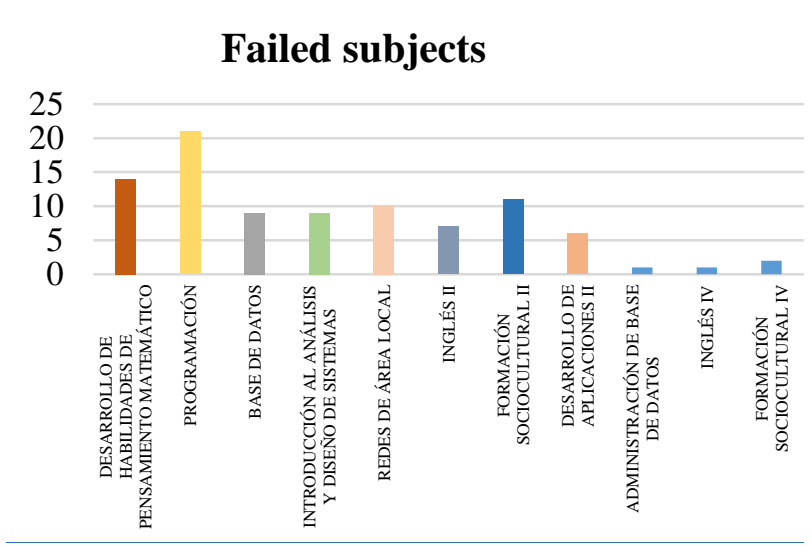

Graphic 2 Failed subjects in the year 2018

For the 2019-1 period, graph 3 shows that the subject of programming is the one with the highest number of students failed for special advice. 


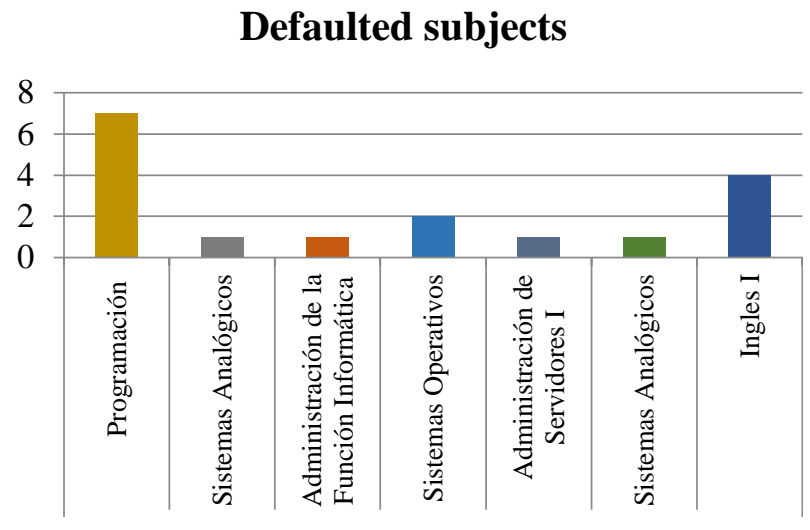

Graphic 3 Materials failed in the period 201-1 Source: own elaboration

The responsibility of the group and individual academic tutoring consists in carrying out tutoreo actions, remedial and complementary courses and others of similar nature.

\section{Hypothesis}

The development of vodcast, will strengthen the teaching and learning process in the subject of Object Oriented Programming and Computer Networks.

\section{Objective}

Develop digital video resources (Vodcasting) as a technological tool to strengthen the teachinglearning process in the academic tutoring of subjects of the curriculum of ICT careers, Areas of Digital Network Infrastructure and Computer Systems.

\section{Specific objectives}

- Make a diagnosis on the opinion of the students to incorporate the videos of complex subjects of the subjects in the consultancies.

- Select the topics that allow generating skills to improve student performance.

- Conduct a technical, economic, operational study to determine the viability of the project.

- Identify the functional and non-functional requirements of the project considering the users (students, teachers).

- Perform the design of Vodcasting with the themes to strengthen based on the learning units of the subjects that make up the areas of knowledge.
- Generate the Vodcast according to the role of the student or teacher.

\section{Justification}

The benefit of carrying out this study is that it will allow Fidel Velázquez Technological University, students and teachers to strengthen the teaching-learning process outside and inside the classroom.

\section{Theoretical framework}

The theoretical foundation of this research is based on the concept of vodcast, digital resource, academic tutoring teaching strategy.

\section{Digital resource}

The ability to create and share information and knowledge has become a key factor in productivity and innovation in economies. Therefore, the current objectives, resources and teaching and learning processes must be reformulated (intef, 2017). A digital resource is any type of information that is stored in digital format, all material used to be manipulated by a computer.

Digital educational resources are materials composed of digital media and produced in order to facilitate the development of activities for learning. (eduteka, 2017).

"A resource can be a content that implies information and / or educational software, characterized by the latter, not only as a resource for education but to be used according to a specific didactic strategy, for example; exercise, practice, simulation, tutorial, hypermedia, hypertext, video, individual use, in small groups, etc. "(Rabajoli, 2012).

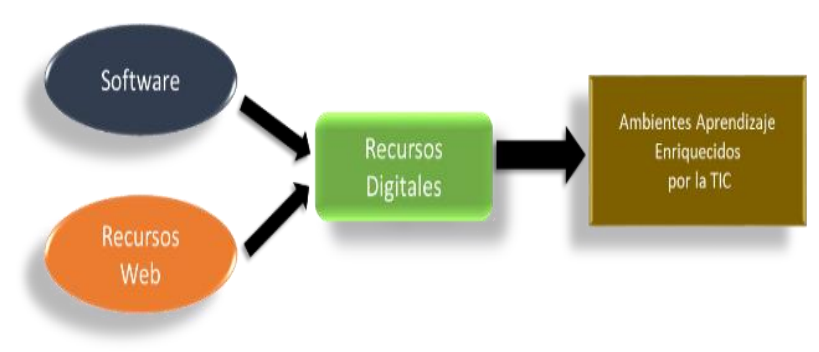

Figure 1 Digital Resources Source: self made 
Educational resources offer new opportunities as elements that reinforce student learning.

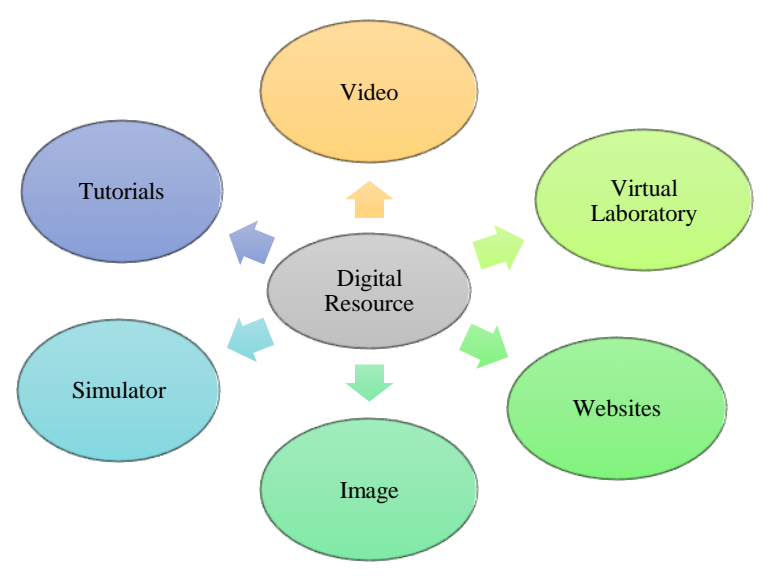

Figure 2 Digital educational resource Source: self made

\section{Vodcasting}

Vodcasting is a digital audio and video file in MP4 format, which is distributed via RSS feed that is automatically downloaded or requested from the Internet so that the user can see it on both a computer and a portable player. It can be used for: Documentaries, descriptive guides of sites of interest, of didactic content, explicit, of own production as a class activity, scientific dissemination, congresses possibility of transmitting presentations, round tables, programs of a TV channel among others.

As Eduteka mentions that the taxonomy proposed by Suzie \& Jane Krauss, there are essential functions that vodcasts must offer to support learning, they are shown in table 1.

\begin{tabular}{|l|l|}
\hline \multicolumn{2}{|c|}{ Function } \\
\hline Ubiquity & $\begin{array}{l}\text { Thescription } \\
\text { these to be viewed at any time and } \\
\text { place, can be downloaded to a } \\
\text { computer or media player to view } \\
\text { without the need for an Internet } \\
\text { connection and published in blogs, } \\
\text { wikis, web pages. }\end{array}$ \\
\hline $\begin{array}{l}\text { Share ideas, } \\
\text { build } \\
\text { community }\end{array}$ & $\begin{array}{l}\text { For Educational Institutions they can } \\
\text { share vodcasts on an educational } \\
\text { platform. }\end{array}$ \\
\hline $\begin{array}{l}\text { Reflection and } \\
\text { iterate / repeat }\end{array}$ & $\begin{array}{l}\text { Teachers and students can make } \\
\text { suggestions about vodcasts and Web } \\
\text { their audio-video products. }\end{array}$ \\
\hline
\end{tabular}

Table 1 Essential functions in support of learning Source: own elaboration
In 2010 Solano defines educational vodcast as a didactic medium with educational content and that is created from a didactic planning process.

\section{Tutorships}

Tutoring is defined as the accompaniment and teaching support of an individual nature, based on personalized attention that favors a better understanding of the problem, for the achievement of academic objectives (ANUIES, 2000). For the Teacher Improvement Program (PRODEP) the tutoring considers it as a form of educational attention where teachers support individually or in a systematic way, through the structuring of objectives, programs, organization by areas, teaching techniques appropriate.

\section{Academic Tutoring.}

Academic tutoring emerges as an alternative to try to improve in students their study and work skills, increasing the probability of success in their studies.

\section{Vodcasting Development}

The stages shown in Figure 3 were taken for the development of vodcast.

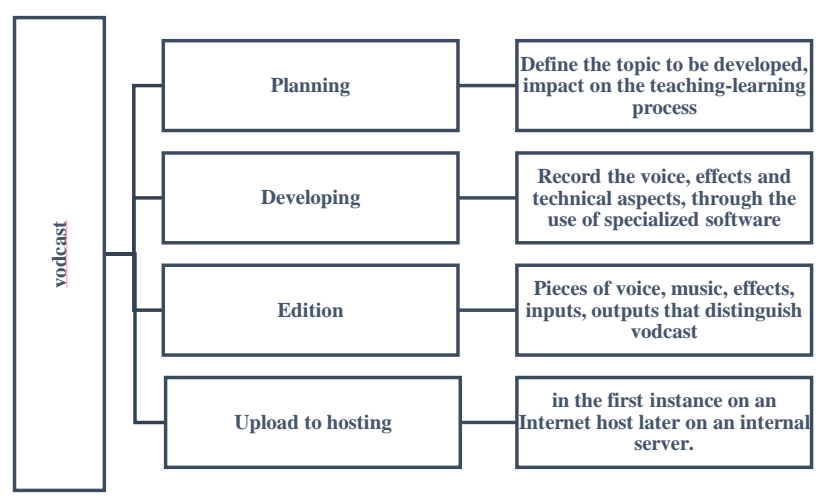

Figure 3 Stages to generate vodcast Source: self made

\section{Stage 1 Planning}

At this stage the topic to be addressed in the vodcast is selected, with an impact on the teaching-learning process.

In planning, the following questions must be answered: 
What is the theme or content?

What will be taught?, What for ?, What do you want to teach?

Pedagogical decisions.

Activity planning.

Technological decisions.

A survey was conducted in which students from both races participated to identify the topic that they consider most complex to understand in the subject-oriented programming subject, resulting in $80 \%$ responding which topic that is most difficult is Control Structures, operation of a counter and accumulator in programming. So the first vodcast was developed to distinguish the operation of a counter and accumulator and propose a solution that contains repetitive control structures to solve a given problem.

\section{Required Software Resources}

Table 2 mentions the software that was used for the generation of vodcast.

\begin{tabular}{|c|c|c|c|c|c|}
\hline Software & Quantity & Unit price & Total & Description & Site \\
\hline $\begin{array}{l}\text { Fre: ac free } \\
\text { audio } \\
\text { converter } \\
\text { Sound } \\
\text { Recorder / } \\
\text { Editor } \\
\text { Audacity }\end{array}$ & 1 & $\$$ & & $\begin{array}{l}\text { It is a free audio } \\
\text { converter and CD } \\
\text { ripper, it works on } \\
\text { Linux, Windows, Mac } \\
\text { operating systems. } \\
\text { Operating systems } \\
\text { provide an elementary } \\
\text { sound recorder that } \\
\text { allows you to record } \\
\text { voice or other sounds. } \\
\text { It is an audio editor and } \\
\text { recorder for Windows, } \\
\text { Mac, Linux. }\end{array}$ & $\begin{array}{l}\text { https://www.fr } \\
\text { eac.org/ }\end{array}$ \\
\hline \begin{tabular}{l|l|} 
Video & \\
Recorder $\quad /$ \\
Editor
\end{tabular} & & $\$$ & & $\begin{array}{l}\text { The operating systems } \\
\text { offer a video recorder } \\
\text { with simple editing } \\
\text { options. }\end{array}$ & \\
\hline $\begin{array}{l}\text { Virtualdub } \\
\text { OpenShot } \\
\text { Video } \\
\text { Editor }\end{array}$ & & $\$$ & & 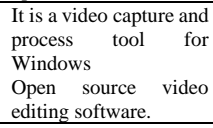 & $\begin{array}{l}\text { https://www.a } \\
\text { udacityteam.or } \\
\mathrm{g} /\end{array}$ \\
\hline Filmora9 & & $\$$ & & $\begin{array}{l}\text { Software to create and } \\
\text { edit videos } \\
\end{array}$ & \\
\hline $\begin{array}{l}\text { MP3, MP4 } \\
\text { players }\end{array}$ & & $\$$ & & $\begin{array}{l}\begin{array}{l}\text { Players that provide } \\
\text { operating systems for } \\
\text { computers, mobile } \\
\text { phones, tablets. }\end{array} \\
\end{array}$ & $\begin{array}{l}\text { http://www.vir } \\
\text { tualdub.org }\end{array}$ \\
\hline $\begin{array}{l}\text { Fre: ac free } \\
\text { audio } \\
\text { converter }\end{array}$ & & $\$$ & & $\begin{array}{l}\text { It is a free audio } \\
\text { converter and CD } \\
\text { ripper, it works on } \\
\text { Linux, Windows, Mac } \\
\text { operating systems. }\end{array}$ & $\begin{array}{l}\text { https://www.o } \\
\text { penshot.org/es }\end{array}$ \\
\hline $\begin{array}{l}\text { Sound } \\
\text { Recorder } \quad / \\
\text { Editor }\end{array}$ & & $\$$ & & $\begin{array}{l}\text { Operating systems } \\
\text { provide an elementary } \\
\text { sound recorder that } \\
\text { allows you to record } \\
\text { voice or other sounds. } \\
\end{array}$ & $\begin{array}{l}\text { https://www.is } \\
\text { kysoft.us/es/fil } \\
\text { mora-video- } \\
\text { editor- } \\
\text { windows.html } \\
\end{array}$ \\
\hline Audacity & & $\$$ & & $\begin{array}{l}\text { It is an audio editor and } \\
\text { recorder for Windows, } \\
\text { Mac, Linux. }\end{array}$ & \\
\hline Total & & $\$ 0.00$ & & & \\
\hline
\end{tabular}

Table 2 Software Resources Source: own elaboration

\section{Hardware Resource}

You can have the basics as:

- Desktop or laptop computer.

- Microphone.

- Video mini camera.

\section{Stage 2 Development}

Once the topic and the population to whom it is addressed were defined. Díaz Lara (2016) proposes for the creation of vodcast:

1. The realization of a script which must be organized by sequences, didactic or content units, the text is detailed, refining the language to be used by orienting it to the target audience, giving it a dynamic and a beginning, a development and an end. Figure 4 shows the literary script of vodcast 1 .

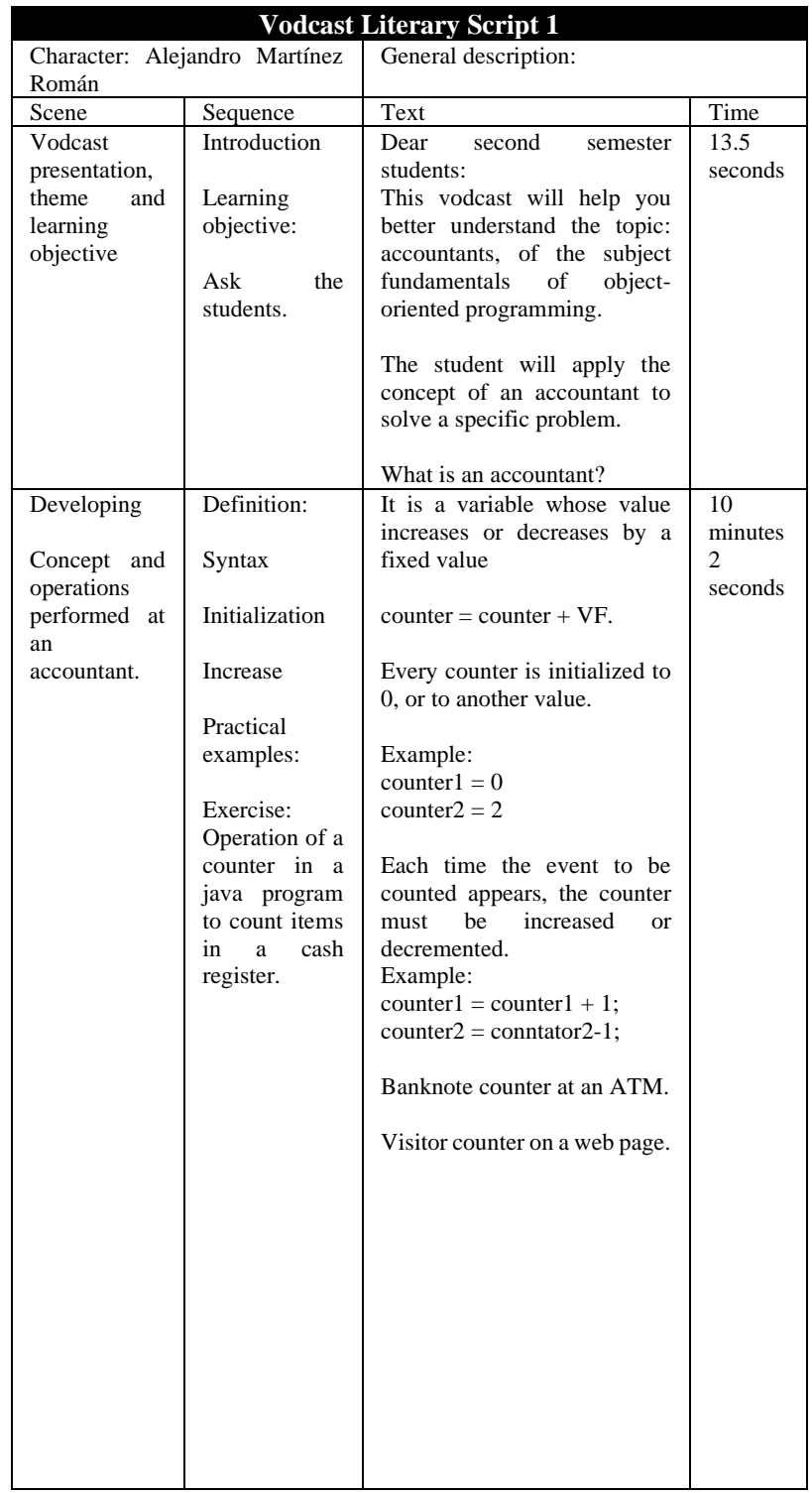

HIDALGO-BAEZA, María del Carmen, HERNÁNDEZ-RAMÍREZ, María Guadalupe, MARTÍNEZ-ROMÁN, Alejandro and CASAS-GÓMEZ, Víctor Guadalupe, MARTINZ-ROMAN, Alejandro and CASAS-GOMEZ, Víctor Manuel. Vodcasting: digital resource for academic tutoring in the methodology of face-to-face teaching of students in the subjects of technological training, networks
and programming. Journal Schools of economic Thought and Methology. 2019 


\begin{tabular}{|l|l|}
\hline & $\begin{array}{l}\text { In the first line of code we } \\
\text { declare the variable meter_art } \\
\text { and initialize it at } 0 \text {, then we } \\
\text { enter the do-while cycle and } \\
\text { read the cost of an article, for } \\
\text { example, 200 and assign it to } \\
\text { the variable quantity, then } \\
\text { following the program flow } \\
\text { we find the if-else instruction, } \\
\text { where } 200 \text { is evaluated equal } \\
\text { to } 0, \text { in this case as if the } \\
\text { condition of if is not met, enter } \\
\text { else and substitute } 0 \text { in the } \\
\text { formula: art_count } \\
\text { art_counter +1, by adding } 0+ \\
1 \text { the new value is } 1 \text { and we } \\
\text { assign it to counter_art, this } \\
\text { means that counter_art has } \\
\text { already been increased by } 1 . \\
\text { If you continue entering } \\
\text { keyboard values other than } \\
\text { zero, then else will be } \\
\text { executed and the counter will } \\
\text { continue to increase to } 2.3 \text { etc. }\end{array}$ \\
\hline
\end{tabular}

Figure 4 Literary script vodcast 1 Accountants and Accumulators

Source: self made

2. The recording of the speech was used Audacity software as editor and audio recorder following the literary script.

\section{Editing Stage}

3. Record music backgrounds using specialized software.

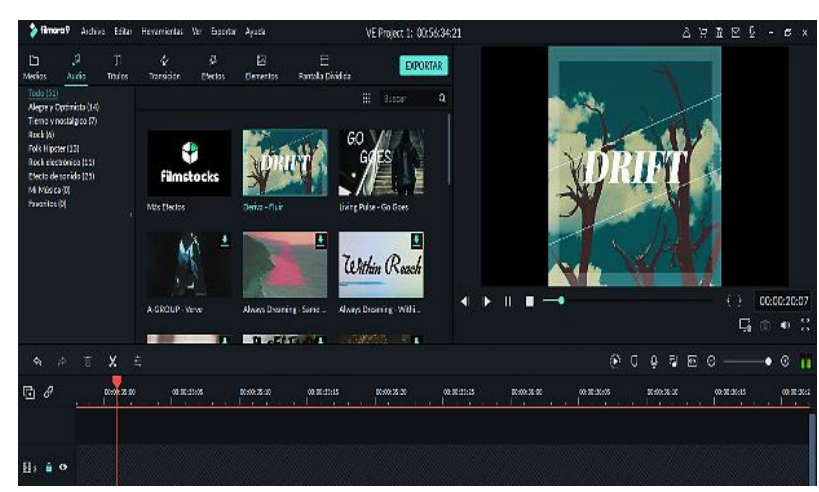

Figure 5 Software for audio selection Source: own elaboration

4. Edit and mix the voice over with the music.

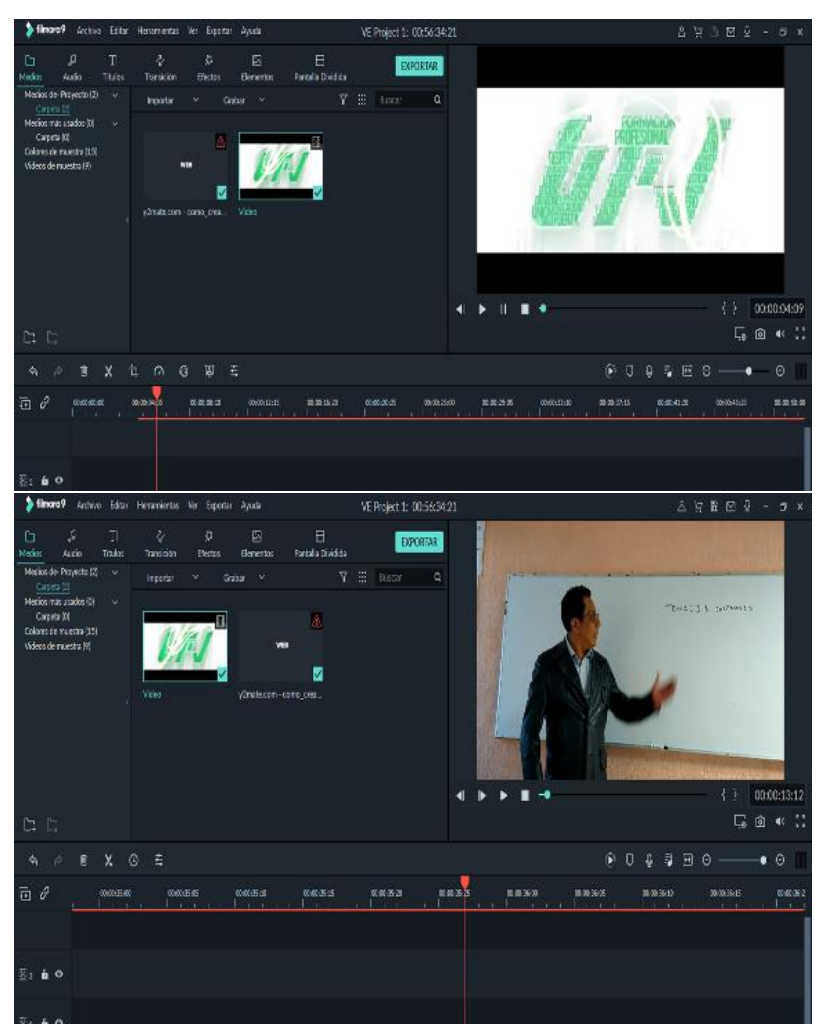

Figure 6 Mix of voice over and music Source: self made

5. Perform export to an audio format compress.

6. Record and select images and their editing and editing in audio.

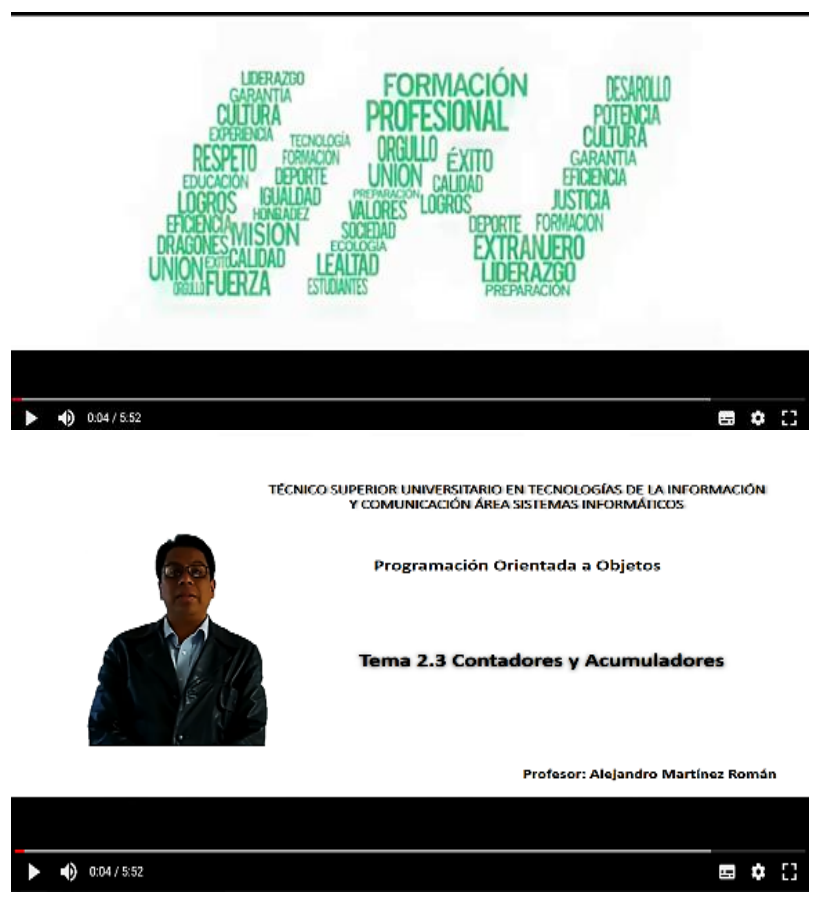

Figure 7 Execution of vodcast Source: own elaboration

The duration of a vodcast would normally not have to exceed ten minutes. 


\section{Research methodology}

A quantitative approach was used, in order to:

- Know the learning style that teachers consider to develop teaching resources.

- Know the teaching resources and learning strategies you use for academic advice with students.

- Know the opinion of teachers to generate a new learning strategy based on (videoaudio).

- Identify student strategies to improve understanding of a topic.

- To know the opinion of the students of incorporating the videos of some subject of greater complexity as a tool of review in consultancies to prevent the rejection.

- Know what aspects should be considered in a video.

The study was conducted with a population size of 8 teachers who teach the programming subject and the second and third-quarter students of the Infrastructure of Digital Networks and Computer Systems careers. For the investigation, a survey was applied and as an instrument two questionnaires were used in Google Drive, the first with 14 closed questions and the second with 8 questions. The results showed that $62.5 \%$ of teachers so that students understand a topic the strategy is collaborative learning and $37.5 \%$ use self-learning as shown in Graphic 4.

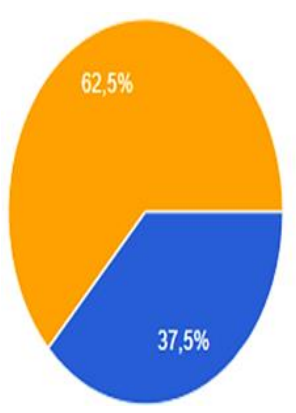

- Autoaprendizaje (Tareas individuales proyectos, investigaciones, solución de ejercicios)

- Aprendizaje interactivo (Exposiciones del docente, conferencias, visitas)

- Aprendizaje colaborativo (Resolución de problemas, discusión grupal)
Graphic 5 shows that $37.5 \%$ consider that to develop digital resources, all learning styles must be considered.

Estilos de aprendizaje

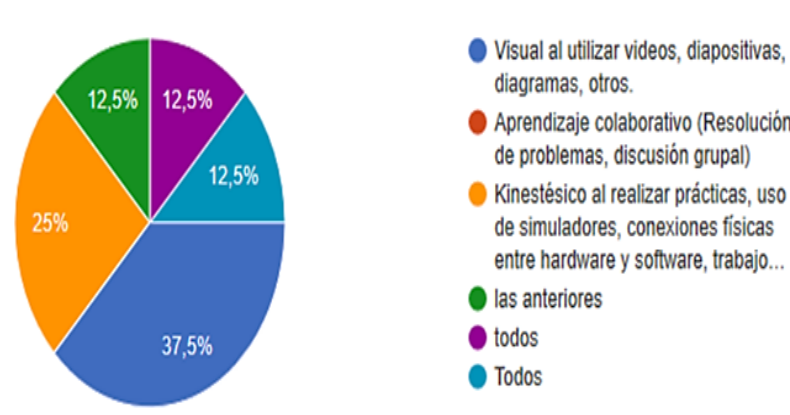

Graphic 5 Learning styles-digital resources Source: self made

Graphic 6 shows that $85.5 \%$ of teachers agree to use vodcast (audio-video) as a teaching resource in academic advice to enhance the different learning styles, visualize and listen to the topics that allow to improve learning and to to visualize the subject through a mobile device, anywhere and when required.

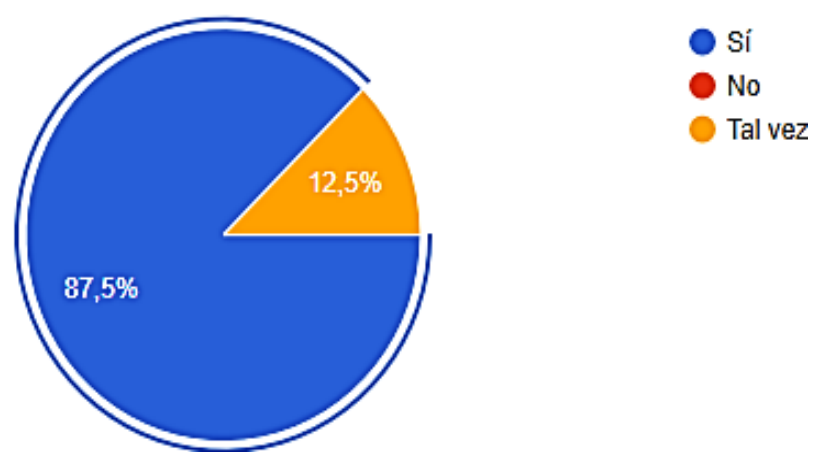

Graphic 6 Incorporate vodcast in academic tutoring Source: self made

The strategies that students use to improve understanding of a topic are shown in Graphic 7.
Graphic 4 Learning strategy Source: self made 


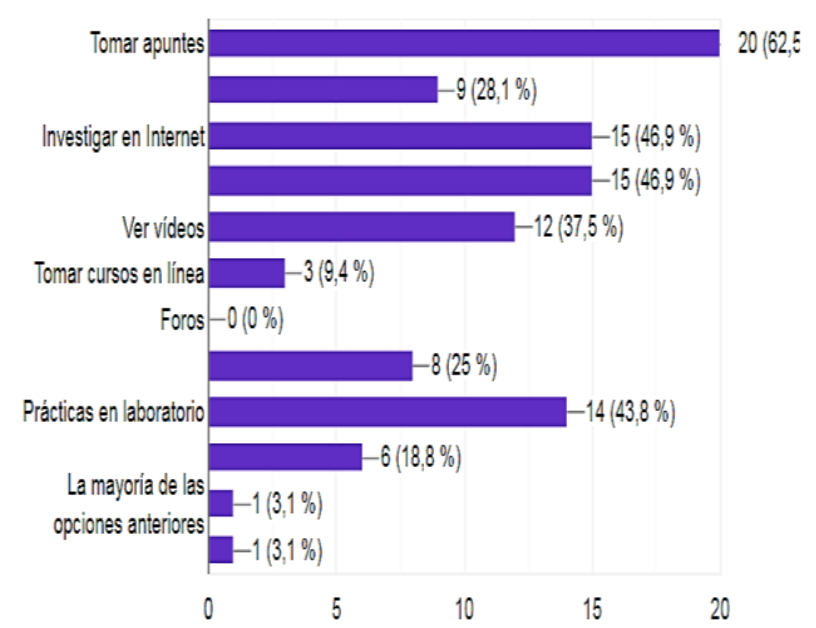

Graphic 7 Strategies for understanding a topic Source: self made

\section{Results}

One of the main factors sought with the development of vodcast is to produce an improvement in academic tutoring. Vodcast will be a self-learning tool due to its availability for easy downloading and saving to a player.

Students will be able to watch it and download the vodcast at any time. The usability of vodcast is simple, allowing the acquisition of knowledge to reinforce learning. In the vodcast the expository technique is used in the presentation of a subject to transmit information of a subject. Vodcast demonstrative practice is used in solving a problem step by step.

In addition, allowing to consolidate and deepen the content presented in person in a class at an appropriate speed.

Graphic 8 shows the result of the survey that was conducted to know the opinion of the students of using vodcast where the result was:

$43.8 \%$ answered that a video on an educational platform would help them, when they do not attend class and want to understand the subject, they do not understand the subject and when they did not review all the topics (teacher absence or teaching method).

$31.3 \%$ when a subject is not understood with the assigned teacher and $21.9 \%$ when they do not attend class and want to understand the subject.

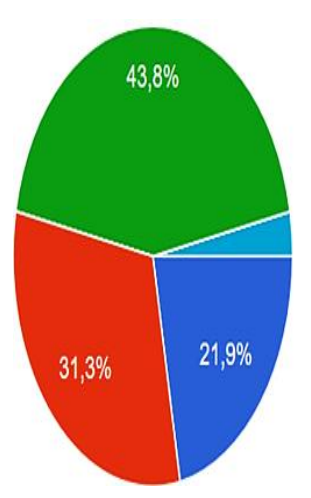

Cuando no asisti a clase y quiero entender el tema

Cuando no comprendo el tema con profesor asignado

Cuando no se revisaron todos los temas (ausencia del profesor 0 método de enseñanza)

Todas

Ninguna

Las primeras 3

Graphic 8 How the video helps students Source: self made

Graphic 9 shows that $90.6 \%$ is important to incorporate videos of the most complex issues and $9.4 \%$ answered that it is not necessary.

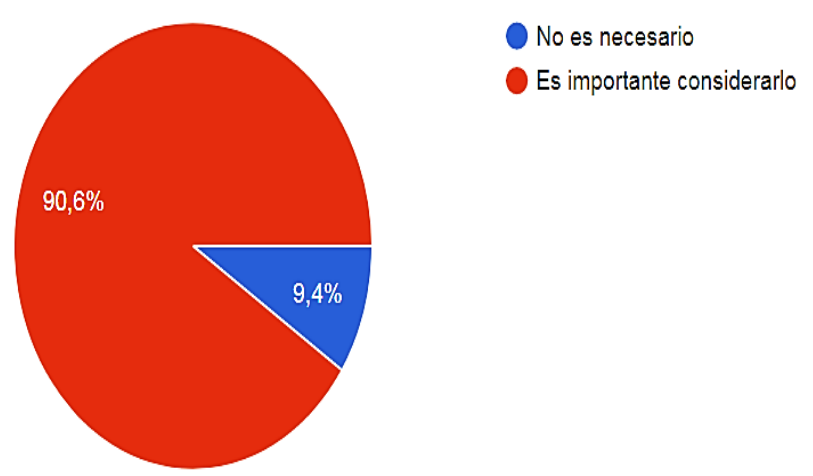

Graphic 9 Incorporate the videos as a support tool Source: own elaboration

\section{Conclusions}

In this work so far the first vodcast that has been developed was presented, but it is sought to develop new recreational materials that strengthen the teaching-learning process and implement more and thus help teachers and students of academic tutoring for the subject Computer Networks, in addition to the productive sector.

Development of recreational materials (manual, videos, animations, interactive activities that strengthen the teaching-learning process.

As a second stage the creation of an educational platform to introduce vodcast in a significant number of chairs. 


\section{References}

ANUIES. (2000). Programas Institucionales de Tutorías, Una propuesta de la ANUIES para su organización y funcionamiento en las Instituciones de Educación Superior.

Díaz Lara, G. (07 de 04 de 2016). Memorias de Producción de Multimedia Educativo. Obtenido: https://producciondemultimediaeducativocezy.b logspot.com/2016/04/el-vodcast-como-recursoeducativo.html

eduteka. (30 de abril de 2017). VII Congreso Virtual Iberoamericano de Calidad en Educación Virtual y Adistancia. Obtenido de: http://eduteka.icesi.edu.co/gp/upload/Recursos_ Educativos_Digitales_que_aportan_al_proceso _de_ensenanza_y_aprendizaje.pdf

intef, I. N. (29 de 03 de 2017). educalab.es. Recuperado el 17 de 05 de 2019: http://educalab.es/intef/tecnologia/recursosdigitales

López García, J. C. (08 de 05 de 14). Universidad ICESI eduteka. Obtenido de: https://eduteka.icesi.edu.co/modulos/8/255/661/ 1 ?url=8/255/661/1

Rabajoli, G. (2012). Recurso digitales para el aprendizaje: una estrategia para la innovación educativa en tiempos de cambio. En G. Rabajoli, Digital (pág. 13). Montevideo Uruguay: Webinar 2012 - IPPE - UNESCO - FLACSO. SEMS. (7 de 03 de 2017). Sistema Nacional de Tutorías Académicas (SiNaTa). Obtenido de: http://www.sems.gob.mx/en_mx/sems/sinata. 